\title{
A TEST OF COMPETITIVE LABOR MARKET THEORY: THE WAGE STRUCTURE AMONG CARE ASSISTANTS IN THE SOUTH OF ENGLAND
}

\author{
STEPHEN MACHIN and ALAN MANNING*
}

\begin{abstract}
This paper examines the structure of wages in a very specific labor market: care assistants in residential homes for the elderly on England's "sunshine coast." This sector corresponds closely to economists' notion of what should be a competitive labor market, both because it has a large number of small firms undertaking a very homogeneous activity in a concentrated geographical area, and because the workers are neither unionized nor covered by any minimum wage legislation, so that there are effectively no external constraints on the wage-setting process. The authors find that the wage structure deviates in important respects from what would be expected in a competitive labor market. In particular, wage dispersion is small within firms, but large between firms; and the wage dispersion that is present does not seem to be closely related to workers' productivity-related characteristics. A test rejects the hypothesis that unobserved labor quality can explain these findings.
\end{abstract}

$\mathbf{T}$ here is a long history in labor economics and industrial relations of studying wages in specific labor markets. This interest dates back to early micro studies of labor markets that emphasized heterogeneity in wage policies across employers (for example, Lester 1946; Slichter 1950; Reynolds 1951). Some more recent work has also studied the issue of within- versus between-employer wage differentials in the United States (Blau 1977; Groshen 1991a, $1991 \mathrm{~b})$. The role played by employers in determining wage structures, however, has received less attention in recent years.
This paper examines the structure of wages in a very specific labor market, for care assistants in residential homes for the elderly on England's southern, "sunshine" coast. It analyzes the results of a postal survey of all such homes conducted in April 1992, data from a follow-up a year later, and a few pieces of information added two years after that. Our interest in this sector arises from the fact that it corresponds closely to economists' notion of what should be a competitive labor market. The sector consists of a large number of small firms undertaking a very homogeneous activity in a concentrated geographical area. The work-

The data used in this paper are available from the second author upon request, at Department of Economics, London School of Economics, Houghton St., London WC2A 2AE, U.K. 
ers they employ are not unionized, nor were they covered by any minimum wage legislation at the time of the data collection (the United Kingdom's National Minimum Wage was introduced only in April 1999; see Machin, Manning, and Rahman [2003] for an analysis of the minimum wage's impact on this sector), so there are effectively no external constraints on the wage-setting process. We think it reasonable to argue that most economists, asked a priori, would think that this market was very competitive.

If it is competitive, what might we expect to see? We would expect to find a single market wage for workers of a given quality. This has two important implications. First, workers of identical quality should receive the same wage in different firms. Second, workers of different quality should receive different wages even if they work in the same firm. In this paper, to determine whether those implications are borne out, we perform a variety of empirical tests that examine wage dispersion within and between firms for care assistants.

\section{Data Description}

The data set used in this paper was obtained from a survey undertaken by us in April 1992 (plus a follow-up a year later) of all (2,036 in total) private-sector residential homes for the elderly located on England's "sunshine coast." (For more details, see Machin, Manning, and Woodland 1993; Woodland 1993.) We were able to sample the entire population of homes by obtaining information on all homes within each county that we consideredDevon, Dorset, Cornwall, Kent, Somerset, and Sussex-since every home for the elderly has to register with the relevant local authority. In Machin, Manning, and Woodland (1993) we documented that the responses we received were highly representative of the entire population of care homes in the counties we sampled with respect to size (number of workers) and the percent in each region.

As noted, this sector was chosen because it closely corresponds to economists' a priori notion of a labor market that should ap- proximate the perfectly competitive model. It consists of a large number of small employers that are engaging in a relatively homogeneous activity (caring for old people) and are geographically concentrated (in some streets in some towns on the south coast of England, almost every second house is a residential care home). Furthermore, most workers in these homes need no formal qualifications: the old people in the homes we consider do not need specialist medical care and, as will be seen below, few workers have a formal nursing qualification.

One other unusual feature of this data set is that we have information on all workers within a large number of firms. This allows us to address issues like the extent of wage variation within and between firms that cannot be considered using most data sets. It is this feature of the data that we will exploit most.

\section{The Structure of Wages in a Low-Wage Labor Market}

The principal occupation of workers employed in these nursing homes is that of Care Assistant, and we focus specifically on the wages of Care Assistants in this paper. Restricting attention to a single job serves our purpose of studying the structure of wages in a very tightly defined labor market.

Even the category "Care Assistant" is not irreducible, however, since we still must choose whether to include only those labeled as day-care assistants or also those recorded as being senior or junior day-care assistants. This is not a trivial decision, as different occupational titles may simply be a way of paying different wages to different individuals and may not signify any real difference in job content. ${ }^{1}$ Most of the results in this paper include those workers labeled as being senior and junior day-care assistants, but we also report some results

\footnotetext{
${ }^{1}$ Baker, Gibbs, and Holmstrom (1994a, 1994b) described this idea, and Manning (1994) worked it out in the context of a search model.
} 
Table 1. Description of the Structure of Hourly Wages

for Care Assistants in Residential Nursing Homes, 1992 and 1993.

\begin{tabular}{|c|c|c|c|c|c|c|c|c|}
\hline \multirow[b]{3}{*}{ Characteristic } & \multicolumn{4}{|c|}{ Cross Sections } & \multicolumn{4}{|c|}{ Matched Sample of Firms } \\
\hline & \multicolumn{2}{|c|}{1992} & \multicolumn{2}{|c|}{1993} & \multicolumn{2}{|c|}{1992} & \multicolumn{2}{|c|}{1993} \\
\hline & $A l l$ & $\begin{array}{c}>5 \\
\text { workers }\end{array}$ & $A l l$ & $\begin{array}{c}>5 \\
\text { workers }\end{array}$ & All & $\begin{array}{c}>5 \\
\text { workers }\end{array}$ & All & $\begin{array}{c}>5 \\
\text { workers }\end{array}$ \\
\hline \multicolumn{9}{|l|}{ All Care Assistants } \\
\hline Number of Individuals & 3,221 & 2,514 & 1,826 & 1,463 & 1,571 & 1,213 & 1,647 & 1,318 \\
\hline Number of Firms & 434 & 246 & 236 & 141 & 213 & 121 & 213 & 124 \\
\hline Average Wage & 2.96 & 2.98 & 3.06 & 3.07 & 2.97 & 2.99 & 3.07 & 3.08 \\
\hline Standard Deviation of & & & & & & & & \\
\hline Log Hourly Wages & .16 & .16 & .16 & .16 & .16 & .16 & .16 & .16 \\
\hline 10th Percentile Wage & 2.45 & 2.50 & 2.50 & 2.50 & 2.45 & 2.50 & 2.50 & 2.50 \\
\hline 25th Percentile Wage & 2.70 & 2.70 & 2.75 & 2.75 & 2.70 & 2.70 & 2.75 & 2.75 \\
\hline 50th Percentile Wage & 3.00 & 3.00 & 3.00 & 3.00 & 3.00 & 3.00 & 3.00 & 3.00 \\
\hline 75th Percentile Wage & 3.20 & 3.25 & 3.30 & 3.30 & 3.20 & 3.25 & 3.30 & 3.34 \\
\hline 90th Percentile Wage & 3.50 & 3.50 & 3.60 & 3.60 & 3.50 & 3.55 & 3.60 & 3.60 \\
\hline \multicolumn{9}{|c|}{ Exclude Junior and Senior Care Assistants } \\
\hline Number of Individuals & 2,878 & 2,246 & 1,603 & 1,271 & 1,363 & 1,057 & 1,441 & 1,154 \\
\hline Number of Firms & 434 & 246 & 235 & 141 & 212 & 121 & 210 & 124 \\
\hline Average Wage & 2.97 & 2.99 & 3.07 & 3.09 & 2.98 & 2.99 & 3.07 & 3.09 \\
\hline \multicolumn{9}{|l|}{ Standard Deviation of } \\
\hline Log Hourly Wages & .15 & .15 & .15 & .15 & .15 & .16 & .15 & .15 \\
\hline 10th Percentile Wage & 2.50 & 2.50 & 2.50 & 2.55 & 2.50 & 2.50 & 2.50 & 2.50 \\
\hline 25th Percentile Wage & 2.70 & 2.73 & 2.77 & 2.77 & 2.70 & 2.70 & 2.75 & 2.75 \\
\hline 50th Percentile Wage & 3.00 & 3.00 & 3.00 & 3.00 & 3.00 & 3.00 & 3.00 & 3.00 \\
\hline 75th Percentile Wage & 3.20 & 3.25 & 3.25 & 3.30 & 3.20 & 3.20 & 3.25 & 3.30 \\
\hline 90th Percentile Wage & 3.50 & 3.50 & 3.60 & 3.60 & 3.50 & 3.55 & 3.60 & 3.60 \\
\hline
\end{tabular}

Notes: Wages are hourly rates defined in British pounds per hour.

using the more narrow definition of daycare assistants only (which tend to strengthen our conclusions).

In Table 1 we report some summary statistics on the distribution of wages in our sample. We have data on 3,221 Care Assistants in 434 homes in 1992 and, from the follow-up of those who responded to that survey, 1,826 Care Assistants in 236 homes in 1993. In our matched sample of 213 homes from which we obtained responses in both years, we have data on around 1,600 Care Assistants in each year. ${ }^{2}$

\footnotetext{
${ }^{2}$ We have not used the data from a handful of single-employee firms, as there is obviously no meaningful difference between firms and workers in these cases and it is this difference on which we wish to focus.
}

Average wages are very low in this sector. In 1992 the mean wage in the matched sample was $£ 2.97$ per hour, and in 1993 it was $£ 3.07$ per hour. In both years, this average was beneath the lowest occupational wage reported in the New Earnings Survey, and was well below the $£ 3.40$ that the Labor Party, prior to the General Election of April 1992, was advocating as a National Minimum Wage. Despite the fact that we are focusing on a very specific occupational group, there is considerable dispersion in hourly wages among these workers. For example, in both years the range between the tenth and ninetieth percentiles of the hourly wage is over one third of

${ }^{3}$ The $90-10$ ratio in this sector is smaller than the $90-10$ ratio in the whole economy, which is 4.2 (source: own calculations on all workers from Labour Force Survey data for 1992-93). 
the median wage. ${ }^{3}$ We also report information on the standard deviation of the log hourly wage. As the wage distribution for the matched sample is very similar to that for the sample as a whole, we use all the observations in what follows.

\section{Wage Variation between and within Companies}

An interesting question is how much of the wage variation described above is between employers (different employers paying different average wages to their work force) and how much is within the same employer (the same employer paying different workers different wages). In Table 2 we present information on the proportion of total variation in the log hourly wage of all care assistants that is inter-firm, the remaining proportion being intra-firm.

In the upper panel of the table one can see that for all care assistants, almost 2/3 of log wage variation is between firms, with only one-third being within firms. Part of the measured inter-firm wage dispersion reflects the variation in wages across different regions, so we also present measures of the importance of inter-firm wage dispersion after introducing geographical controls. We use 16 regional controls in the regressions below, and to control for town we rely on postal addresses (this is a very disaggregated measure, as there are then 129 towns in our sample). As one would expect, introducing finer regional dummies reduces the measured importance of inter-firm wage dispersion, but even with the town dummies, the proportion of interfirm wage dispersion remains close to $50 \%$. As one might be concerned that the results are driven by the existence of many small firms, we also present the variance decomposition for workers who are in care homes with more than five workers; the results are very similar.

To help put these figures in perspective, we also computed the proportions of the observed variance in other personal characteristics that are inter-firm and intra-firm. We have information on age, job tenure, and hours, so we use a variance decomposi- tion of the log of all these variables. These results are also reported in Table 2 . What is striking is that whatever geographical controls are used, the proportion of variation that is inter-firm is much higher for wages than for any other variable-typically twice as high. Thus, of all the variables on which we have data, wages have the smallest proportion of total variance within firms. The finding that there is a lot of wage variation between employers in a given labor market is one on which there has been a lot of research (for example, the older papers of Lester [1946], Reynolds [1946, 1951], and Slichter [1950], and the more recent Krueger and Summers [1988]), but, as far as we are aware, this has not been tied to the lack of wage variation within employers. ${ }^{4}$ Our finding that there is extraordinarily little wage variation within firms is even stronger when we restrict attention to day-care assistants only (Table 2 , bottom panel).

To reinforce the point that there is surprisingly little wage dispersion within firms, we now present some further information on the structure of wages within firms. These results are reported in Table 3. First, about a third of firms, containing $25 \%$ of workers, have no within-firm variation in wages; that is, in these firms all Care Assistants receive exactly the same wage. Another third of firms, employing about a third of workers, pay only two different wages. Only one firm pays all its workers different wages. These wage policies seem very stable. Of the 213 firms in the matched sample, in 26 wage dispersion existed in 1992 but not in 1993, and in 26 the reverse was true-wage dispersion was not present

\footnotetext{
${ }^{4}$ One should note that this result would be likely to change in an analysis that looks at the dispersion in wages across occupations, as the wage gap between managers and care assistants in every firm far exceeds the cross-firm dispersion in care assistants' pay. Thus, for example, the findings of Abowd et al. (1999), who considered all occupations and concluded that individual-specific effects are more important than firm effects, are not inconsistent with the findings reported here.
} 
Table 2. Proportion of Dispersion That Is Inter-Firm.

\begin{tabular}{|c|c|c|c|c|c|c|}
\hline \multicolumn{2}{|l|}{ Description } & Year & $\log ($ wage $)$ & $\log ($ age $)$ & $\log ($ tenure $)$ & $\log$ (hours) \\
\hline \multicolumn{7}{|l|}{ All Care Assistants } \\
\hline \multirow[t]{6}{*}{ All Workers } & No Controls & 1992 & .64 & .23 & .29 & .34 \\
\hline & & 1993 & .65 & .20 & .27 & .34 \\
\hline & Area Controls & 1992 & .59 & .23 & .30 & .33 \\
\hline & & 1993 & .60 & .21 & .26 & .33 \\
\hline & Town Controls & 1992 & .47 & .16 & .23 & .21 \\
\hline & & 1993 & .48 & .15 & .18 & .20 \\
\hline \multirow{6}{*}{$\begin{array}{l}\text { Workers in Firms } \\
\text { with More Than } \\
5 \text { Workers }\end{array}$} & No Controls & 1992 & .63 & .19 & .25 & .30 \\
\hline & & 1993 & .66 & .17 & .24 & .28 \\
\hline & Area Controls & 1992 & .56 & .18 & .27 & .28 \\
\hline & & 1993 & .60 & .17 & .22 & .26 \\
\hline & Town Controls & 1992 & .37 & .10 & .17 & .14 \\
\hline & & 1993 & .40 & .09 & .14 & .11 \\
\hline \multicolumn{7}{|l|}{ Day-Care Assistants } \\
\hline \multirow[t]{6}{*}{ All Workers } & No Controls & 1992 & .74 & .25 & .32 & .36 \\
\hline & & 1993 & .80 & .20 & .30 & .36 \\
\hline & Area Controls & 1992 & .68 & .24 & .33 & .35 \\
\hline & & 1993 & .76 & .21 & .29 & .35 \\
\hline & Town Controls & 1992 & .57 & .18 & .26 & .24 \\
\hline & & 1993 & .65 & .15 & .21 & .23 \\
\hline \multirow{6}{*}{$\begin{array}{l}\text { Workers in Firms } \\
\text { with More Than } \\
5 \text { Workers }\end{array}$} & No Controls & 1992 & .72 & .20 & .28 & .31 \\
\hline & & 1993 & .80 & .16 & .27 & .29 \\
\hline & Area Controls & 1992 & .65 & .19 & .30 & .30 \\
\hline & & 1993 & .75 & .17 & .25 & .28 \\
\hline & Town Controls & 1992 & .48 & .11 & .20 & .16 \\
\hline & & 1993 & .59 & .10 & .15 & .12 \\
\hline
\end{tabular}

in 1992 but was present in 1993; but of these 52 firms with a change, in 29 the change involved the wage of only a single worker, and there were only a handful of cases of large changes in wage structures.

If attention is restricted to larger firms (those with more than five workers), one finds that the proportion of both workers and firms with no wage dispersion falls. From this, one might be tempted to conclude that there is more wage dispersion in larger firms than in smaller ones. But such a conclusion would be premature, since there are also more opportunities for wage dispersion in larger firms than in smaller ones. One would like to have some way to normalize the measure of wage dispersion by firm size.

One possible way to accomplish that end is the following. Suppose that all existing workers in the firm are paid the same wage and, conditional on this fact, the probability that an extra worker is paid the same wage is $\rho$. Then the probability that a firm with $N$ workers will have no wage dispersion is given by $\rho^{N-1}$. We used the information on the existence or nonexistence of wage dispersion to estimate $\rho .^{5}$ The results are reported in the last row of Table 3. For all firms, the spot estimate of $\rho$ is 0.76 , so that, given that all existing workers are paid the same wage, the probability that an additional worker will be paid that wage is $76 \%$. Once we restrict attention to firms with more than five workers, the estimate of $\rho$

\footnotetext{
${ }^{5}$ Note that in making this estimation we do not use all the information about the number of different wages paid in the firm, nor do we allow $\rho$ to differ with each additional worker.
} 
Table 3. Measures of Intra-Firm Wage Dispersion.

\begin{tabular}{|c|c|c|c|c|}
\hline \multirow[b]{2}{*}{ Description } & \multicolumn{2}{|c|}{ All Workers } & \multicolumn{2}{|c|}{$\begin{array}{l}\text { Workers in Firms with } \\
\text { More Than } 5 \text { Workers }\end{array}$} \\
\hline & 1992 & 1993 & 1992 & 1993 \\
\hline Number of Workers & 3,221 & 1,826 & 2,514 & 1,463 \\
\hline Number of Firms & 434 & 236 & 246 & 138 \\
\hline Proportion of Workers in Firms with Single Wage & .26 & .25 & .23 & .21 \\
\hline Proportion of Firms with Single Wage & .31 & .32 & .25 & .25 \\
\hline Proportion of Workers in Firms with Two Wages & .30 & .35 & .25 & .33 \\
\hline Proportion of Firms with Two Wages & .35 & .37 & .27 & .33 \\
\hline $\begin{array}{l}\text { Proportion of Hours Paid the Modal Hourly Wage } \\
\text { (PROPMOD) }\end{array}$ & .76 & .76 & .74 & .73 \\
\hline $\begin{array}{l}\text { Proportion of Hours Paid the Modal Wage in Firms } \\
\text { with Wage Dispersion }\end{array}$ & .65 & .64 & .65 & .65 \\
\hline Average Standard Deviation of Log Hourly Wages & .06 & .06 & .07 & .06 \\
\hline $\begin{array}{l}\text { Average Standard Deviation of Log Hourly Wages in } \\
\text { Firms with Wage Dispersion }\end{array}$ & .09 & .09 & .09 & .08 \\
\hline Estimated Probability of Same Wage (standard error) & $.76(.010)$ & $.77(.012)$ & $.83(.007)$ & $.84(.002)$ \\
\hline
\end{tabular}

Notes: The final five rows of this table are means across firms. The means across individuals (not reported here) are very similar.

rises to 0.83 , a difference that is statistically significant. Thus, there is a sense in which wage dispersion is less common in large firms than in smaller firms.

The criterion for wage dispersion that we have used so far is a very liberal one. If a firm compensates even one hour of labor at a rate different from that for the rest of its hours, it is classed as having wage dispersion. To evaluate the data using measures that allow for more subtle shading, in Table 3 we present a number of alternative specifications. First, we report the proportion of total hours worked by care assistants that are paid the modal hourly wage. As one can see, about $75 \%$ of hours are paid the modal rate, a proportion that seems extremely high. However, this statistic tells us little about the extent of the variation in wages, so we also present data on the hoursweighted standard deviation of log hourly wages.

So far, we have documented that there is surprisingly little wage dispersion within firms, but considerable heterogeneity across firms. Our initial reaction to these results is to think that it is a long way from the "law of one wage" predicted by competitive la- bor markets: there seems to be "too much" wage variation across firms and "too little" within them. However, we have not presented a formal test of the hypothesis that the observed distribution of wages is the outcome of a competitive labor market, that is, one in which all workers are paid their marginal product. That is the subject of the next section.

\section{Are the Data Consistent with the Perfectly Competitive Model?}

If all workers are paid their marginal product, then the workers in the firms with zero wage dispersion must all have the same marginal product. Prima facie, this is surprising, as there is variation within these firms in observable characteristics that we might expect to be related to worker quality. In our data set the available "quality" variables are age, sex, tenure, and qualifications. Table 4 presents descriptive statistics on these variables at both individual and firm level both for the whole sample and for the sample divided according to whether or not the firm has any wage dispersion. If the competitive model were correct, we 
might expect to see less variation in observable characteristics within firms with no dispersion, but as can be seen from the lower panel of Table 4, there is very little evidence for this.

However, this finding does not clinch the case against the competitive model, as our measures of worker quality are inevitably imperfect and it seems likely that there is an important component of worker quality that is observable to employers but not to us. In general, this is an intractable problem, but the availability of one other possible measure of worker quality holds out at least some hope of progress. In the particular market considered here, it seems reasonable to suppose that higher-quality workers are advantageous to employers because, other things equal, they deliver a higher quality of care and thus enable employers to charge residents higher prices. We therefore propose to use the price as an indirect measure of worker quality. ${ }^{6}$

Let us denote the quality of a worker by $q$ and assume that $q$ can be written as

$$
q=\beta x+\varepsilon,
$$

where $\beta x$ represents the effect of observable characteristics and $\varepsilon$ the effect of unobservable characteristics. There is no particular reason to believe that $\varepsilon$ is uncorrelated with $x$ : in fact, if the competitive model is to be able to explain the lack of wage dispersion in some firms, then it cannot be. If the labor market is competitive, then $w=q$, where $w$ is the measured wage (one could also allow measurement error in this). A regression of the wage on the observed characteristics $x$ will estimate

$$
E(w \mid x)=\beta x+E(\varepsilon \mid x)=\beta^{*} x .
$$

Table 5 presents estimates of earnings equations at both the individual level and the firm level, for the whole sample, for only

\footnotetext{
${ }^{6}$ As we have price information only at the firm level, we can only see if the variation in worker characteristics across firms is associated with variation in prices; we cannot examine whether wage dispersion in those firms where it exists rewards the more productive workers.
}

those firms with wage dispersion, and for only those firms without it. We also include the log of patients per worker hour as a measure of the intensity of worker effort, the log of the number of residents as a measure of the size of the home, and a dummy variable for whether the home is part of a larger organization.

For the whole sample, the estimated wage equation is very familiar: wages are a concave function of age, increasing in job tenure, and are higher for qualified workers and higher in larger firms. There is no premium for male workers, but there are very few men in the sample. Large firms and homes with high numbers of patients per worker hour are found also to pay higher wages. When the sample is restricted to firms with wage dispersion, similar results obtain. But when a wage equation for workers in firms without wage dispersion is estimated, tenure and qualifications are no longer statistically significant, ${ }^{7}$ and the wage effect of age, while statistically significant, is only about a sixth of its magnitude in the firms with wage dispersion. An implication of the return to age in this subsample is that firms with a tendency to pay higher wages tend to end up with workers of a particular age. Only the effects of the firm-level variables seem to be the same as (or even slightly larger than) before.

Furthermore, these differences between firms with and without wage dispersion are statistically significant: a Chow test for the equality of the coefficients in the two regressions leads to $F(25,4407)=11.57$ for the individual equations and $F(25,543)=$ 2.20 for the firm-level equations, both of

\footnotetext{
${ }^{7}$ This finding does have implications for the empirical literature on whether the returns to tenure in cross-sectional wage equations are spurious (see, for example, Abraham and Farber 1987; Altonji and Shakotko 1987; Marshall and Zarkin 1987; Topel 1991). In particular, we know that in the elder care homes without wage dispersion, any measured returns to tenure must be spurious, since within these homes high-tenure workers do not receive higher wages. As we find no such returns, the return to tenure in the cross-section must be interpreted as being largely the result of some firms paying their high-tenure workers higher wages.
} 
Table 4. Descriptive Statistics.

\begin{tabular}{|c|c|c|c|c|c|c|}
\hline \multirow[b]{2}{*}{ Description } & \multicolumn{3}{|c|}{1992} & \multicolumn{3}{|c|}{1993} \\
\hline & All & $\begin{array}{c}\text { Firms with } \\
\text { No Wage } \\
\text { Dispersion } \\
(\text { DSPRSN = 0) }\end{array}$ & $\begin{array}{c}\text { Firms with } \\
\text { Wage } \\
\text { Dispersion } \\
(\text { DSPRSN > 0) }\end{array}$ & All & $\begin{array}{c}\text { Firms with } \\
\text { No Wage } \\
\text { Dispersion } \\
(\text { DSPRSN =0) }\end{array}$ & $\begin{array}{c}\text { Firms with } \\
\text { Wage } \\
\text { Dispersion } \\
(\text { DSPRSN > 0) }\end{array}$ \\
\hline \multicolumn{7}{|l|}{ Individual Level } \\
\hline Number of Workers & 3,221 & 827 & 2,394 & 1,826 & 452 & 1,374 \\
\hline Hourly Wage & $2.96(.49)$ & $2.97(.42)$ & $2.96(.51)$ & $3.06(.50)$ & $3.05(.42)$ & $3.07(.52)$ \\
\hline Age & $36.5(14.1)$ & $38.7(13.3)$ & $35.7(14.2)$ & $36.9(14.0)$ & $38.6(13.2)$ & $36.4(14.3)$ \\
\hline Tenure & $2.5(2.7)$ & $2.5(2.5)$ & $2.6(2.7)$ & $2.7(2.6)$ & $2.6(2.4)$ & $2.7(2.7)$ \\
\hline Proportion Male & .03 & .02 & .03 & .03 & .01 & .04 \\
\hline $\begin{array}{l}\text { Proportion with Nursing } \\
\text { Qualification }\end{array}$ & .05 & .03 & .05 & .05 & .05 & .05 \\
\hline DSPRSN & .74 & .00 & 1.00 & .75 & .00 & 1.00 \\
\hline ProPMOD ${ }^{\mathrm{a}}$ & .73 & 1.00 & .64 & .74 & 1.00 & .65 \\
\hline Number of Workers & $10.1(5.7)$ & $8.4(4.3)$ & $10.7(6.1)$ & $10.1(5.1)$ & $7.8(3.7)$ & $10.9(5.2)$ \\
\hline Number of Residents & $17.1(9.6)$ & $13.8(6.4)$ & $18.2(10.2)$ & $17.1(9.2)$ & $12.8(5.7)$ & $18.6(9.6)$ \\
\hline Patients per Worker Hour & $.091(.050)$ & $.075(.070)$ & $.089(.042)$ & $.086(.045)$ & $.089(.044)$ & $.086(.046)$ \\
\hline Part of Larger Organization & .077 & .075 & .078 & .056 & .091 & .045 \\
\hline Price of Bed & $195(29)$ & $194(33)$ & $195(28)$ & $208(34)$ & $204(34)$ & $209(33)$ \\
\hline \multicolumn{7}{|l|}{ Firm Level } \\
\hline Number of Firms & 432 & 135 & 297 & 231 & 74 & 157 \\
\hline Average Hourly Wage & $2.97(.39)$ & $2.95(.40)$ & $2.97(.39)$ & $3.09(.42)$ & $3.00(.39)$ & $3.13(.43)$ \\
\hline $\begin{array}{l}\text { Within-Firm Standard } \\
\text { Deviation of Log Hourly } \\
\text { Wages }\end{array}$ & $.026(.039)$ & .00 & $.039(.042)$ & $.024(.036)$ & 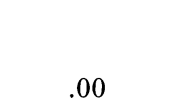 & $.036(.039)$ \\
\hline Average Age & $37.4(7.8)$ & $39.6(8.2)$ & $36.4(7.4)$ & $37.2(7.3)$ & $38.5(8.2)$ & $36.6(6.8)$ \\
\hline $\begin{array}{l}\text { Within-Firm Standard } \\
\text { Deviation of Age }\end{array}$ & $4.9(2.8)$ & $5.0(3.1)$ & $4.8(2.7)$ & $4.8(2.8)$ & $4.7(3.0)$ & $4.8(2.8)$ \\
\hline Average Tenure & $2.6(1.6)$ & $2.5(1.7)$ & $2.6(1.6)$ & $2.7(1.5)$ & $2.7(1.6)$ & $2.8(1.4)$ \\
\hline $\begin{array}{l}\text { Within-Firm Standard } \\
\text { Deviation of Tenure }\end{array}$ & $.76(.79)$ & $.74(.85)$ & $.77(.76)$ & $.76(.68)$ & $.69(.58)$ & $.79(.72)$ \\
\hline Average Proportion Male & .03 & .03 & .03 & .03 & .02 & .03 \\
\hline $\begin{array}{l}\text { Average Proportion Nursing } \\
\text { Qualification }\end{array}$ & .06 & .04 & .06 & .07 & .06 & .07 \\
\hline DSPRSN & .68 & .00 & 1.00 & .68 & .00 & 1.00 \\
\hline PrOPMOD $^{a}$ & .76 & 1.00 & .65 & .76 & 1.00 & .64 \\
\hline Number of Workers & $7.1(4.4)$ & $6.0(3.8)$ & $7.6(4.5)$ & $7.5(4.3)$ & $6.0(3.3)$ & $8.2(4.5)$ \\
\hline Number of Residents & $13.8(7.3)$ & $11.6(5.5)$ & $14.7(7.8)$ & $14.2(7.9)$ & $11.0(5.5)$ & $15.7(8.5)$ \\
\hline Patients per Worker Hour & $.111(.070)$ & $.131(.097)$ & $.102(.051)$ & $.103(.060)$ & $.104(.053)$ & $.102(.062)$ \\
\hline Part of Larger Organization & .049 & .045 & .050 & .047 & .067 & .038 \\
\hline Price of Bed & $190(25)$ & $188(28)$ & $191(24)$ & $201(29)$ & $197(28)$ & $204(30)$ \\
\hline
\end{tabular}

Means are presented with standard deviations in parentheses.

${ }^{\text {aPROPMOD: }}$ proportion of hours paid the modal hourly wage.

which are convincing rejections of the null hypothesis. If the competitive model is correct, these findings imply that the correlation of observed characteristics with un- observed characteristics must be different in the two segments; that is, if we define a binary variable, DSPRSN, that takes the value 1 if there is wage dispersion and zero if 
Table 5. Estimated Wage Equations.

(Dependent Variable: Log Hourly Wage)

\begin{tabular}{|c|c|c|c|c|c|c|}
\hline \multirow[b]{2}{*}{ Independent Variable } & \multicolumn{3}{|c|}{ Individual Level } & \multicolumn{3}{|c|}{ Firm Level } \\
\hline & $A l l$ & $\begin{array}{c}\text { Firms with } \\
\text { No Wage } \\
\text { Dispersion } \\
(\text { DSPRSN = 0) }\end{array}$ & $\begin{array}{c}\text { Firms with } \\
\text { Wage } \\
\text { Dispersion } \\
(\text { DsPRSN > 0) }\end{array}$ & $A l l$ & $\begin{array}{l}\text { Firms with } \\
\text { No Wage } \\
\text { Dispersion } \\
(\text { DsPRSN = O) }\end{array}$ & $\begin{array}{c}\text { Firms with } \\
\text { Wage } \\
\text { Dispersion } \\
(\text { DSPRSN > 0) }\end{array}$ \\
\hline Age / 10 & $.18(.009)$ & $.030(.014)$ & $.21(.010)$ & $.22(.04)$ & $.06(.08)$ & $.28(.05)$ \\
\hline Age Squared/100 & $-.021(.001)$ & $-.003(.002)$ & $-.024(.001)$ & $-.026(.004)$ & $-.006(.009)$ & $-.033(.005)$ \\
\hline Tenure $/ 10$ & $.10(.008)$ & $.006(.014)$ & $.12(.009)$ & $.12(.03)$ & $.001(.006)$ & $.16(.04)$ \\
\hline Male & $.006(.013)$ & $-.010(.026)$ & $.009(.014)$ & $-.021(.051)$ & $-.036(.085)$ & $-.012(.063)$ \\
\hline \multicolumn{7}{|l|}{ Nursing } \\
\hline Qualification & $.062(.010)$ & $-.034(.018)$ & $.075(.011)$ & $.037(.033)$ & $-.124(.066)$ & $.056(.037)$ \\
\hline Log Residents & $.036(.004)$ & $.068(.008)$ & $.032(.005)$ & $.032(.010)$ & $.052(.020)$ & $.022(.011)$ \\
\hline \multicolumn{7}{|l|}{ Log Patients per } \\
\hline Worker Hour & $.053(.009)$ & $-.028(.007)$ & $.036(.006)$ & $.019(.010)$ & $-.020(.017)$ & $.049(.012)$ \\
\hline \multicolumn{7}{|l|}{ Part of Larger } \\
\hline Organization & $.053(.009)$ & $-.015(.015)$ & $.070(.011)$ & $.029(.023)$ & $.005(.047)$ & $.038(.026)$ \\
\hline \multicolumn{7}{|l|}{ Number of } \\
\hline Observations & 4,407 & 1,012 & 3,395 & 584 & 171 & 413 \\
\hline R-Squared & .29 & .44 & .31 & .32 & .42 & .39 \\
\hline Standard Error & .14 & .10 & .14 & .11 & .11 & .11 \\
\hline
\end{tabular}

Notes: Standard errors in parentheses. All regressions also include a year dummy and 16 area dummies.

The firm-level wage equations are weighted by the number of residents for comparison with the price equations in the Table 6.

there is not, then $E(\varepsilon \mid x$, DsPrSN $=1) \neq E(\varepsilon \mid$ DSPRSN $=0$ ).

Now let us turn to an analysis of the determinants of the price. Suppose that the relationship between price and worker quality is given by

$$
p=\gamma_{0} z+\gamma_{1} q+v,
$$

where $z$ is a vector of observed factors that affect price apart from worker quality (some or all of which may be contained in $x$ ) and $v$ is unobserved factors that affect the quality of care. Now, when one runs a regression of $p$ on $x$ and $z$, one will be estimating

$$
\begin{gathered}
E(p \mid x, z)=\gamma_{0} z+\gamma_{1} E(q \mid x, z) \\
+E(v \mid x, z)=\gamma_{0} z+\gamma_{1} \beta^{*} x+E(v \mid x, z) .
\end{gathered}
$$

The rationale for the test is that if we estimated price equations across the segments of the market for which we have shown from the wage equation that the correlation of quality with characteristics (that is, $\left.\beta^{*}\right)$ is different, we would also expect to find corresponding differences in the price equations.

The results of this exercise are reported in Table 6. The first column estimates a price equation for the whole sample, and the next two columns divide the sample into the firms with and without wage dispersion. In this sector, the Department of Social Security pays a subsidy for the care of many residents up to a maximum of $£ 175$ per week. ${ }^{8}$ One consequence is that there is a spike in the price distribution at this price and very few homes charge lower prices. Accordingly, we treated the price equation as an equation for the desired price and then estimated a tobit model with $£ 175$ as the lower censoring point. The results for the whole sample (column 1)

${ }^{8}$ The actual system of subsidy is more complicated than this, as it involves means-testing, but it is this upper bound on payments that seems to have the most effect on the market. 
suggest that price is significantly related to the log of patients per worker hour (a measure of quality of care), the size of the home, whether the home is part of a larger organization, and (among the worker characteristics) the average age. This is consistent with a casual reading of job advertisements in this sector, which emphasize employers' preference for older workers.

The second and third columns estimate separate price equations for firms with and without wage dispersion. What is striking is that the coefficients (on age in particular) are very similar in the two subsamples. A formal test cannot reject the hypothesis of equality of coefficients, with a likelihood ratio test yielding $\chi^{2}(25)=19.26$ (the critical value at the $5 \%$ level is 38 ). This is inconsistent with the competitive model, which, given the evidence on wages, would predict significant differences between the two segments. Hence, we conclude that unobservable worker quality cannot reconcile the observed wage data with the perfectly competitive model, and that the evidence from the price equations suggests close similarity between homes with and without wage dispersion in the correlation between unobserved worker quality and observed worker quality. ${ }^{9}$

A comparison of the wage equations in Table 5 with the price equations in Table 6 also shows that the worker characteristics associated with higher wages are not necessarily associated with higher prices. In particular, job tenure is associated with significantly higher wages but significantly lower prices. This is consistent with previously published empirical findings indicating that the worker characteristics associated with higher wages are not necessarily associated with higher worker quality (see, for example, Medoff and Abraham 1980, 1981; Klein, Spady, and Weiss 1991). One way to explain these results while retaining

${ }^{9}$ The one possible case in which this will not work is where $E(v l, z, x)$ also differs across the segments in a way that exactly offsets the worker quality effect-and this seems a thin straw at which to clutch.
Table 6. Estimated Price Equations. (Firm-Level; Dependent Variable $=$ Log Price $)$

\begin{tabular}{|c|c|c|c|}
\hline $\begin{array}{l}\text { Independent } \\
\text { Variable }\end{array}$ & All & $\begin{array}{c}\text { Firms with } \\
\text { No Wage } \\
\text { Dispersion } \\
(\text { DSPRSN = 0) }\end{array}$ & $\begin{array}{c}\text { Firms with } \\
\quad \text { Wage } \\
\text { Dispersion } \\
(\text { DsPRSN > 0) }\end{array}$ \\
\hline Age $/ 10$ & $.25(.06)$ & $.28(.12)$ & $.20(.07)$ \\
\hline $\begin{array}{l}\text { Age Squared/ } \\
100\end{array}$ & $-.031(.007)$ & $-.038(.015)$ & $-.024(.009)$ \\
\hline Tenure/10 & $-.14(.05)$ & $-.23(.10)$ & $-.12(.06)$ \\
\hline $\begin{array}{l}\text { Male } \\
\text { Nursing }\end{array}$ & $-.059(.072)$ & $.032(.119)$ & $-.13(.095)$ \\
\hline Qualification & $-.027(.049)$ & $-.23(.11)$ & $.022(.057)$ \\
\hline Log Residents & $.069(.014)$ & $.089(.031)$ & $.066(.017)$ \\
\hline $\begin{array}{l}\text { Log Patients } \\
\text { per Worker }\end{array}$ & & & \\
\hline Hour & $-.060(.015)$ & $-.069(.025)$ & $-.050(.019)$ \\
\hline $\begin{array}{l}\text { Part of Larger } \\
\text { Organization }\end{array}$ & $.096(.032)$ & $.044(.064)$ & $.115(.037)$ \\
\hline $\begin{array}{l}\text { Number of } \\
\text { Observations }\end{array}$ & 564 & 169 & 395 \\
\hline Log-Likelihood & 39.4 & 10.0 & 39.0 \\
\hline Standard Error & .15 & .14 & .14 \\
\hline
\end{tabular}

Notes: Standard errors in parentheses. All regressions also include a year dummy and 16 area dummies.

The price equations have a tobit specification with a lower cut-off at $\ln (175)$.

a competitive view of the labor market might be to appeal to the existence of specific human capital. The wage paid is then determined by productivity in the next-best alternative, and there is no reason why worker characteristics should not affect worker quality in this firm independent of the wage paid. The main reason we do not find this explanation of our findings plausible is that the traditional variable used to measure the extent of firm-specific human capital is job tenure. The Becker (1975) argument is that workers capture some but not all of the returns to specific human capital, so that wages rise with job tenure (as shown in the All Workers columns of Table 5), but not as fast as productivity does. However, the estimates in Table 6 show that this is not the case.

To summarize, we have explored further whether the structure of wages we observe is consistent with the competitive model. We have argued that it is not, and that traditional "get-outs" like unobserved la- 
bor quality are implausible explanations of what is observed in the data.

\section{Alternative Models of the Structure of Wages}

Given the results reported above, we do not think the competitive model is especially helpful for understanding the particular labor market analyzed here. The "law of one wage" in which there is a uniform market wage for workers of each quality ranking does not seem to hold. But is there a more successful alternative? Any theory that successfully explains our data must explain why there is so little wage dispersion within firms, why the wage dispersion that does exist within firms does not seem to be closely related to productivity, and why apparently identical firms seem to have different wage policies that are stable over time.

In this section, we consider five alternative classes of models of the structure of wages that have been proposed: rent-sharing models, monopsony models, incentive models, fairness models, and implicit contract models. Not all of these are noncompetitive-implicit contract models and some fairness models, for example, posit a single wage for labor of a given type-but all five model types imply some deviation from a competitive spot market. The ideas behind these theories overlap considerably, so one should not think of them as necessarily mutually exclusive.

\section{Rent-Sharing Models}

These models have become popular in recent years as a way to explain the dispersion in wages between firms (see, for example, Christofides and Oswald 1992). The argument is that there are quasi-rents in all employment relationships and that workers (whether in unions or not) have the ability to extract a share of these rents. As there is likely to be heterogeneity in quasirents across firms, the result will be heterogeneity in wages.

This rent-sharing theory obviously has potential application to the inter-firm wage variability, but it does not seem persuasive as an explanation of the structure of wages within firms. There are no trade unions in any of the firms in our sample, so any bargaining that does occur must be at an individual level. But given individuals' heterogeneity, we would expect the outcome of this individual bargaining to be considerable wage dispersion within firms, which the data do not show. It is simply not credible to think of wages in the firms with no wage dispersion as being negotiated individually with each worker: it seems beyond reasonable doubt that the single wage paid is determined unilaterally by the firm. However, it is quite possible that in some circumstances in some firms, a valued worker gets a raise when he or she threatens to leave, so some of the wages we observe are probably determined by some kind of bargaining.

\section{Incentive Models}

There has also been a considerable amount of literature emphasizing how, in the presence of problems of worker moral hazard or shirking, firms may pay wages that diverge from marginal products. Examples of this type of theory are Lazear (1981) and Akerlof and Katz (1989). In this type of model, upward-sloping wage profiles are offered to workers because this provides incentives for them to exert effort so as not to lose their jobs.

Incentive models have generally been used to explain why within-firm wage variation might sometimes exceed the variation in marginal products, which seems to be the case in, for example, the firms considered by Medoff and Abraham $(1980,1981)$. Our data set, however, poses the opposite question: why do employers with workers who presumably differ in productivity choose to pay all their workers the same wage? Incentive models clearly are not suited to explaining this important feature of our data set.

\section{Fairness and Status Theory}

One obvious candidate for explaining why there is so little wage dispersion within 
firms is the possibility that workers dislike wage dispersion and believe that all workers doing the same job should be paid the same wage even though some of them may do the job more effectively than others. Theories based on this premise have a long tradition and have recently been invoked by a number of authors (for example, Akerlof and Yellen 1990; Frank 1984); Bewley (1999) suggested that such a theory could be of use in explaining labor market outcomes. The relevant literature in psychology generally supports the basis for fairness and status theories. It seems plausible that the dynamic highlighted by these theories is an important factor behind the "single-wage" policy pursued by many employers.

\section{Implicit Contracts}

Another type of economic theory that might be used to explain the lack of wage dispersion within firms is implicit contract theory (see Rosen [1986] for a survey). The basic idea is that risk-averse workers are unable to insure against various employment risks in the insurance market and instead buy insurance from their employers, who are generally assumed to be riskaverse. In this case the ex ante labor market is competitive, but observed wages and employment will not, as a rule, be the equilibrium of a spot market. This model has most commonly been used to explain the lack of wage variation over time, but it could also conceivably be used to explain the lack of variation in wages across workers who are being insured against variation in their productivity (see Harris and Holmstrom [1982] for a more formal model of this type).

For a number of reasons, we are skeptical about the relevance of this sort of model to the labor market we are considering here. First, there is no explicit wage contract guaranteeing insurance, so any insurance contract must be implicit and enforced on the side of the firm by reputation effects. Yet, these are small firms for whom we would not expect reputation effects to be very important. Furthermore, average job tenure in this sector is only about three years, so firms can offer only a limited amount of insurance. Second, workers should only be able to purchase insurance against variation in productivity that is ex ante unobservable. Yet the estimated wage equations of Table 5 suggest that workers in firms with no wage dispersion also manage to obtain insurance against their age, which should not be possible. Third, the fact that owner-managed firms are very common in this sector means that owners are unlikely to be risk-neutral.

One fundamental difficulty is that implicit contract models do not seem to represent the right way to think about the structure of wage policies in the type of labor market under consideration. Care workers, who are overwhelmingly part-time and low-paid, and whose jobs are usually short-lived, seem extremely unlikely parties to implicit contracts, as do their employers.

\section{Monopsony}

A large number of labor market models have been designed to explain the existence of equilibrium wage dispersion between firms (for example, Albrecht and Axell 1984; Burdett and Mortensen 1998; Lang 1991; Montgomery 1991). Because all of these models assume that the labor supply curve facing a firm is not perfectly elastic, they allow for some degree of monopsony (see Manning [2003] for more extensive discussion of monopsony in labor markets). In these models, high- and low-wage firms can coexist in equilibrium, because high-wage firms have larger work forces in equilibrium or lower turnover costs. Our finding of a robust positive correlation between wages and firm size supports this prediction. But in all of these models, one assumption is that all workers within firms are paid the same wage; no convincing explanation for this is offered.

In fact, there is a good reason to expect to see the emergence of wage dispersion within firms in this sort of model: appropriately chosen wage dispersion can increase profits, essentially because it allows a firm 
to act as a discriminating monopsonist rather than the simple monopsonist assumed in the models.

Such wage dispersion might be effected through a formal structure, such as an explicit wage scale relating wages to tenure, which will tend to bind workers to the firm (see Ioannides and Pissarides [1983] for an example of this form of argument). Alternatively, wage dispersion could be created more informally by paying low wages to those with poor outside opportunities, and by raising the wages of workers who receive outside offers. For example, in the Burdett and Mortensen (1998) model, workers are paid wages that are below marginal products and leave when they receive a better wage offer. There are obvious incentives for the firm to pay a higher wage to a worker who has just received an outside wage offer and is about to quit. However, the structure of wages within the firm is determined not just by productivity, so this kind of model can explain why the wage dispersion that does exist is often unrelated to productivity.

The problem that remains is to explain why there is so little wage dispersion within firms. One possible line of explanation is suggested by thinking about the consequences of a firm's adopting a strategy of matching outside wage offers. Workers in a firm that adopts this strategy have an obvious incentive to generate or even invent outside wage offers. Workers in a firm with a wage structure responsive to outside wage offers will therefore likely report more outside wage offers than workers in a firm that does not vary wages, and their average wages will likely be higher as a result. Thus, while wage dispersion offers the possibility of reducing turnover of valued workers, it also will tend to raise average wages.

A similar sort of idea is behind Ellingsen and Rosen (2003). In that model, firms have a choice of paying a fixed wage to all workers or negotiating wages with individual workers. The disadvantage of the first strategy is that the firm will fail to hire or retain some workers who are disenchanted with the fixed wage and whose productivity is such that they would be profitable to the firm if they could be paid the wage they desire. On the other hand, if wages are negotiated individually, wages are higher on average, but all efficient matches are consummated. In Ellingsen and Rosen's model, both strategies co-exist in equilibrium (that is, they offer the same level of profits), a prediction that seems to comport very well with our data.

\section{Summary and Conclusions}

Most microeconomic data sets lack sufficient detail to permit a close examination of the structure of wages in a specific labor market. In this paper we have used data on a reasonably large sample of workers and firms in a very particular labor market that, given its structure, we feel most economists would expect to be competitive. Upon examination, however, it is hard to avoid the conclusion that there are very serious limitations to the usefulness of the competitive model in explaining the data. In particular, we feel that the competitive model cannot explain one of the most striking patterns our evidence revealsthe presence of very little wage dispersion within firms, and of high wage dispersion between firms. Moreover, what wage dispersion there is does not seem to be closely related to the characteristics of workers that seem to be associated with high productivity.

We find that the proportion of wage dispersion that is inter-firm, versus intrafirm, is typically twice as high as the similar proportion for any other variable for which we have measured individual variation. In fact, about 1 in 4 workers work in firms in which all care assistan ts get paid the same hourly wage, and another third of workers are in firms with only two different hourly wages. These firms do not have significantly less variation in observable characteristics among their workers than do firms in which wage dispersion is present.

Of course, a believer in the relevance of the competitive model could plausibly argue that our measures of worker quality are far from perfect and that the distribution of 
unobservable worker quality could be such as to make the data consistent with the competitive model. Our test of this hypothesis rejects it, however. Specifically, we show that firms with wage dispersion differ substantially from those without wage dispersion in the correlation between observed worker characteristics and wages, but are very similar in the correlation between the prices charged to residents (an indirect measure of worker quality) and worker characteristics.

We conclude from the examination of these data that the competitive model is not particularly helpful for understanding the structure of wages in this labor market. What, then, should be put in its place? We review five alternative theories of the wage structure, discussing their strengths and weaknesses for the purpose of explaining our data. No one theory emerges as the explanation, but we do come to a number of general conclusions.

First, frictions in this labor market are substantial enough to accommodate considerable and long-lasting heterogeneity in the wage policies of employers without some firms suffering a catastrophic reduction in profits. These frictions can account for the heterogeneity in wages across employers, as was emphasized by earlier micro studies of labor markets (for example, Lester 1946; Slichter 1950; Reynolds 1951). Second, the lack of wage dispersion within firms is probably driven by two factors: worker dislike of wage heterogeneity on grounds of "fairness," and employer avoidance of wage heterogeneity in order to keep worker demands for wage increases to a minimum. However, these conclusions, while consistent with our data, must remain somewhat tentative. It seems plausible that, for the small employers in this sector, there is an opportunistic aspect to wage policy, with wages being determined on an ad hoc basis as events evolve. For example, a particularly valued worker's threat to leave may cause an employer to break an otherwise closely followed "one-wage" policy. If this is the case, then outside observers are always likely to have a hard time explaining why particular wage structures are observed in particular firms.

We therefore think it is helpful to view firms in the labor market as having considerable discretion in the setting of wages, a discretion that has its roots in labor market frictions. They seem to use this discretion to have very simple wage structures, probably because of worker dislike of wage variation among workers doing the same job and reluctance on the part of employers to allow the possibility of individual negotiation of wages. However, these speculations need to be subjected to more formal testing.

\section{REFERENCES}

$\rightarrow$ Abowd, John, Francis Kramarz, and David Margolis. 1999. "High Wage Workers and High Wage Firms." Econometrica, Vol. 67, No. 2 (March), pp. 251-334.

$\rightarrow$ Abraham, Katharine G., and Henry S. Farber. 1987. "Job Duration, Seniority, and Earnings." American Economic Review, Vol. 77, No. 3 (June), pp. 278-97.

$\rightarrow$ Akerlof, George, and Lawrence Katz. 1989. "Workers' Trust Funds and the Logic of Wage Profiles." Quarterly Journal of Economics, Vol. 104, No. 3 (August), pp. 525-36.

$\rightarrow$ Akerlof, George, and Janet Yellen. 1990. "The FairWage Effort Hypothesis and Unemployment." Quarterly Journal of Economics, Vol. 105, No. 2 (May), pp. 255-83.

$\rightarrow$ Albrecht, James, and Bo Axell. 1984. "An Equilibrium Model of Search Unemployment." Journal of Political Economy, Vol. 92, No. 5, pp. 824-40.

$\rightarrow$ Altonji, Joseph G., and Robert A. Shakotko. 1987.
"Do Wages Rise with Job Seniority?" Review of Economic Studies, Vol. 54, No. 3 (July), pp. 437-59.

$\rightarrow$ Baker, George, Michael Gibbs, and Bengt Holmstrom. 1994a. "The Internal Economics of the Firm: Evidence from Personnel Data." Quarterly Journal of Economics, Vol. 109, No. 4 (November), pp. 881919.

1994b. "The Wage Policy of a Firm." Quarterly Journal ofEconomics, Vol. 109, No. 4 (November), pp. 921-55.

Becker, Gary. 1975. Human Capital, 2nd edition. Chicago: University of Chicago Press.

Bewley, Truman. 1999. Why Wages Don't Fall During a Recession. Cambridge, Mass.: Harvard University Press.

Blau, Francine. 1977. Equal Pay in the Office. Lexington, Mass.: D.C. Heath. 
Differentials, Employer Size, and Unemployment." International Economic Review, Vol. 39, No. 2, pp. 257-73.

$\rightarrow$ Christofides, Louis, and Andrew Oswald. 1992. "Real Wage Determination and Rent-Sharing in Collective Bargaining Agreements." Quarterly Journal of Economics, Vol. 107, No. 3 (August), pp. 985-1002.

$\rightarrow$ Ellingsen, Tore, and Asa Rosen. 2003. "Fixed or Flexible? Wage Setting in Search Equilibrium." Economica, Vol. 70, No. 5, pp. 233-50.

$\rightarrow$ Frank, Robert. 1984. "Are Workers Paid Their Marginal Product?" American Economic Review, Vol. 74, No. 5, pp. 549-71.

$\rightarrow$ Groshen, Erica. 1991a. "Sources of Intra-Industry Wage Dispersion: How Much Do Employers Matter?" Quarterly Journal of Economics, Vol. 106, No. 2 (May), pp. 869-84.

1991b. "Five Reasons Why Wages Vary among Employers." Industrial Relations, Vol. 30, No. 3 (Fall), pp. 350-81.

$\rightarrow$ Harris, Milton, and Bengt Holmstrom. 1982. "A Theory of Wage Dynamics." Review of Economic Studies, Vol. 49, No. 3 (July), pp. 315-33.

$\rightarrow$ Ioannides, Yannis, and Christopher Pissarides. 1985. "Monopsony and the Lifetime Relation between Wages and Productivity." Journal of Labor Economics, Vol. 3, No. 1, Part 2 (January), pp. 91-100.

$\rightarrow$ Klein, Roger, Richard Spady, and Andrew Weiss. 1991. "Factors Affecting the Output and Quit Propensities of Production Workers." Review of Economic Studies, Vol. 58, pp. 929-53.

$\rightarrow$ Krueger, Alan B., and Lawrence H. Summers. 1988. "Efficiency Wages and the Inter-Industry Wage Structure." Econometrica, Vol. 56, No. 2 (March), pp. 25993.

$\rightarrow$ Lang, Kevin. 1991. "Persistent Wage Dispersion and Involuntary Unemployment." Quarterly Journal of Economics, Vol. 106, No. 1 (February), pp. 181-202.

$\rightarrow$ Lazear, Edward. 1981. "Agency, Earnings Profiles, Productivity, and Hours Restrictions." American Economic Review, Vol. 71, No. 4 (September), pp. 606-20.

$\rightarrow$ Lester, Richard. 1946. "Wage Diversity and Its Theoretical Implications." Review of Economics and Statistics, Vol. 28, No. 1 (February), pp. 152-59.

$\rightarrow$ Machin, Stephen, Alan Manning, and Lupin Rahman. 2003. "Where the Minimum Wage Bites Hard: The Introduction of the UK National Minimum Wage to a Low Wage Sector.” Journal of the European Economic Association, Vol. 1, No. 1, pp. 154-80.

Machin, Stephen, Alan Manning, and Stephen Woodland. 1993. "Are Workers Paid Their Marginal Product? Evidence from a Low Wage Labour Market.” Discussion Paper No. 93-09, University College London.

Manning, Alan. 1994. "Labour Markets with Company Wage Policies." Centre for Economic Performance, London School of Economics, Discussion Paper 214.

2003. Monopsony in Motion. Princeton: Princeton University Press.

$\rightarrow$ Marshall, Robert, and Gary Zarkin. 1987. "The Effect of Job Tenure on Wage Offers." Journal of Labor Economics, Vol. 5, No. 3 (July), pp. 301-24.

$\rightarrow$ Medoff, James L., and Katharine G. Abraham. 1980. "Experience, Performance, and Earnings." Quarterly Journal of Economics, Vol. 95, No. 4 (December), pp. 703-36.

1981. "Are Those Paid More Really More Productive? The Case of Experience." Journal of Human Resources, Vol. 16, No. 2 (Spring), pp. 186216.

Montgomery, James. 1991. "Social Networks and Labor-Market Outcomes: Toward an Economic Analysis." American Economic Review, Vol. 81, No. 5 (December), pp. 1407-18.

$\rightarrow$ Reynolds, Lloyd. 1946. "The Supply of Labor to the Firm." Quarterly Journal of Economics, Vol. 60, pp. $390-411$.

1951. The Structure of Labor Markets: Wages and Labor Mobility in Theory and Practice. Westport, Conn.: Greenwood Press.

Rosen, Sherwin. 1986. "Implicit Contracts: A Survey." In Orley Ashenfelter and Richard Layard, eds., Handbook of Labor Economics, Volumes 1-2. Amsterdam: North-Holland, pp. 1144-75.

$\rightarrow$ Slichter, Sumner. 1950. "Notes on the Structure of Wages." Review of Economics and Statistics, Vol. 32, No. 1 (February), pp. 80-91.

$\rightarrow$ Topel, Robert. 1991. "Specific Capital, Mobility, and Wages: Wages Rise with Job Seniority." Journal of PoliticalEconomy, Vol. 99, No. 1 (February), pp. 14576.

Woodland, Stephen. 1993. "Who Cares for the Workers?" Centre for Economic Performance, London School of Economics, Working Paper 426. 